\title{
Impaired glucose tolerance in a middle-aged male urban population: a new approach for identifying high-risk cases
}

\author{
K.-F. Eriksson and F. Lindgärde \\ Department of Medicine, University of Lund, Malmö General Hospital, Malmö, Sweden
}

\begin{abstract}
Summary. From an urban population $(n=9,033)$ of $47-49$ year-old males, 6,956 participated in a multiphase screening programme, of whom $1.5 \%$ were already registered as diabetic patients, $1.7 \%$ were then found to be diabetic; of 6,325 subjects given oral glucose tolerance tests, $6.6 \%$ were found to have impaired glucose tolerance (WHO criteria, 1985). In 889 asymptomatic cases with initial capillary whole blood glucose values $\geq 6.6 \mathrm{mmol} / \mathrm{l}$ fasting and/or $2 \mathrm{~h}$ postload, fluctuation in oral glucose tolerance was studied at repeat tests within one month; the mean differences in glucose values between the first and second test were $<-1 \%$ (fasting) and $-15 \%$ ( $2 \mathrm{~h}$ post-load); there were no differences in body weight, and $62 \%$ of those with initially impaired glucose tolerance had normalised by the repeat test. Only in 109 cases $(1.7 \%)$ were $2 \mathrm{~h}$ post-load values in the 7.8 $11.0 \mathrm{mmol} / \mathrm{l}$ range both at the first and the repeat test; these
\end{abstract}

cases were comparable vis-à-vis body mass index, triceps skin fold, blood pressure and initial glucose and insulin values, but had significantly lower oxygen uptake $(2.34 \pm 0.54 \mathrm{l} / \mathrm{min}$ vs $2.63 \pm 0.68 \mathrm{l} / \mathrm{min} ; p<0.003)$, as compared with subjects with initially impaired glucose tolerance but normal repeat test outcome. However, subjects with high normal first test results ( $2 \mathrm{~h}$ value in the $7.0-7.7 \mathrm{mmol} / \mathrm{l}$ range) and second test results in the $7.0-11.0 \mathrm{mmol} / 1$ range, resembled those with persistent impairment of glucose tolerance in all respects (including oxygen uptake). The repeat test procedure (including ergometry), is therefore to be recommended in selecting true risk cases.

Key words: Diabetes mellitus, impaired glucose tolerance, population study, oral glucose tolerance test reproducibility, body weight, oxygen uptake.
Type 2 (non-insulin-dependent) diabetes mellitus develops from a preliminary phase of impaired glucose tolerance (IGT) to manifest disease after an interval of varying duration [1-13]. The oral glucose tolerance test (OGTT) has been regarded as the best procedure for the diagnosis of mild diabetes in fasting normoglycaemic subjects [14], but there is a considerable divergence in the definition of IGT between that of the National Diabetes Data Group (based on midtest and $2 \mathrm{~h}$ value) [15] and that of the WHO (based on the $2 \mathrm{~h}$ value alone) [16]. A central problem has been identifying those really at risk [17], as there is a high incidence of spontaneous improvement or normalisation of glucose tolerance which is seldom taken into account when cases of IGT are selected for prospective study. Individual fluctuation has been demonstrated both in glucose tolerant subjects [18-20] and in IGT cases [20], but not in a large series with $2 \mathrm{~h}$ values ranging from high normal to diabetic levels.

The aim of the present study was to make an epidemiological survey of impaired glucose tolerance and diabetes mellitus in a well-defined urban population of middle-aged males, and to identify the approximate $5 \%$ of the population who, though non-diabetic, are at the highest risk of developing diabetes, and thus select a group of suitable size for prospective study, where intervention would be justified and for which adequate resources for follow-up are available. Owing to the low predictive value of a single glucose tolerance test, a repeat test procedure was used to identify those with reproducible test results.

\section{Subjects and methods}

\section{Study population}

Since 1974, the Preventive Medicine Section of the Department of Medicine at Malmö General Hospital, has run a continuous health screening and intervention programme for the consecutive investigation by birth-year cohorts of the city population [21,22]. During a 5-year period, all 47-49-year-old Malmö males, born 1926-1931, were invited to participate, $77 \%$ of whom accepted (Fig. 1). 
The Malmö prospective diabetes cohort study

Males born 1926-1931

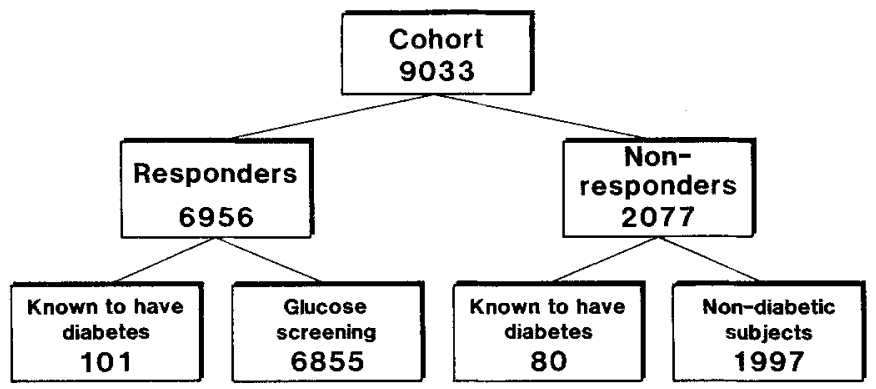

Fig. 1. Cohort structure and prevalence of known diabetes mellitus in Malmö, Sweden, at the time of screening, during the period 1974 1979

Fasting blood glucose was analysed in all cases. A glucose tolerance test was included in the screening procedure, except in the case of known diabetic subjects or those with overt diabetic symptoms. In cases of IGT or newly detected diabetes, and in a random sample of the population screened, submaximal ergometry was performed.

\section{Methods}

All investigations were performed after the subjects had fasted (from 22.00 hours) overnight for at least $10 \mathrm{~h}$ and had refrained from smoking that morning. No other changes in life-style or diet during the days immediately preceding screening were requested. Compliance was checked before investigation, and in cases where the instructions had not been followed or sudden illness had intervened, investigation was postponed.

Blood glucose in capillary whole blood from fingertip samples was analysed with specific methods $[23,24]$. Body mass index (BMI) was calculated according to the formula: $\mathrm{kg} / \mathrm{m}^{2}$. The triceps skin fold index was obtained by caliper measurement over the right brachial triceps, $5 \mathrm{~cm}$ above the elbow, values being transformed into a $\log$ scale [25]. Blood pressure was measured after $10 \mathrm{~min}$ rest. Plasma insulin was measured by standard RIA [26], and blood lipids with standard methods. Maximal oxygen uptake was estimated from steady state heart rate during submaximal ergometry [27], values being expressed in $1 / \mathrm{min}$ and $\mathrm{ml} \cdot \mathrm{kg}^{-1} \cdot \min$.

The glucose tolerance test (GTT) was performed with the subjects at rest, lying at a $45^{\circ}$ angle, and only rising to void urine. For OGTT, $30 \mathrm{~g}$ glucose $/ \mathrm{m}^{2}$ body surface area (according to du Bois) $(58 \pm 5 \mathrm{~g}$; mean and SD) in $10 \%$ aqueous solution was ingested within $5 \mathrm{~min}$ [28]. Fasting and $2 \mathrm{~h}$ blood glucose was measured in duplicate, and plasma insulin in triplicate. From the first two birth-year cohorts, cases were randomly selected for an intravenous test (IVGTT) in which $25 \mathrm{~g}$ glucose $/ \mathrm{m}^{2}(49 \pm 14 \mathrm{~g})$ in $40 \%$ aqueous solution was injected within $3 \mathrm{~min}$ and the $\mathrm{k}$-value $(\% / \mathrm{min})$ calculated [29].

\section{Cut-off levels for GTT}

At screening, the cut-off levels adopted for the OGTT and IVGTT were those routinely used in the hospital [28]. The cut-off level adopted for fasting and $2 \mathrm{~h}$ post-load (OGTT) capillary whole blood glucose was $6.6 \mathrm{mmol} / \mathrm{l}$ at the start of the screening programme, but after introduction of the SI-system during the second year the cut-off level for the $2 \mathrm{~h}$ value was approximated to $7.0 \mathrm{mmol} / \mathrm{l}$. For the epidemiological survey presented here, however, the WHO (1985) criteria for diabetes and IGT have been used [16]. For the IVGTT kvalue, the cut-off level for a normal test was $1.00 \% / \mathrm{min}$.

\section{Second GTT}

To check an abnormal or diabetic result of the first fasting value or GTT, with a few exceptions all such cases were invited to a second test within one month. The letter of invitation to the repeat test, stated only that the GTT result was abnormal and should be checked; no other information was given. In cases with diabetic symptoms or high fasting glucose levels, only fasting values were checked; in cases of abnormal test results, the GTT was repeated. The oral test was repeated in 889 cases with abnormal results. In another 88 cases, the first test was an OGTT and the second test an IVGTT, and vice versa in 69 cases (randomly selected). In 20 cases, IVGTT was performed twice. The test was not repeated in some cases (for various reasons).

\section{Statistical analysis}

Values for variables are expressed as means and SD or SEM. Paired $t$-tests were used for comparing glucose values and body weights between first and second OGTT. Tables 2 and 5 show the results of analysis of variance, $t$-tests between groups having been done where $F$ values were significant $(p<0.05)$.

\section{Results}

\section{Diabetes prevalence (Figs. 1 and 2)}

Of the total cohort at the time of the invitation to join the programme, $77 \%$ responded while $23 \%$ did not respond despite two requests. Of the responders, the prevalence of previously known diabetes was $1.5 \%$ of which $34 \%$ were on insulin treatment, $0.2 \%$ of cases with previously unknown diabetes had overt symptoms of diabetes and glycosuria, while $1.5 \%$ were asymptomatic meeting the WHO criteria (1985) for diabetes at the first GTT. Thus, the prevalence of newly detected diabetes was $1.7 \%$, and the total prevalence of diabetes in the responder group $3.1 \%$. In a further 32 cases $(0.5 \%)$, repeat test results indicated the presence of diabetes. All newly detected cases were preliminarily regarded as Type 2 diabetic patients, and none were put on insulin treatment.

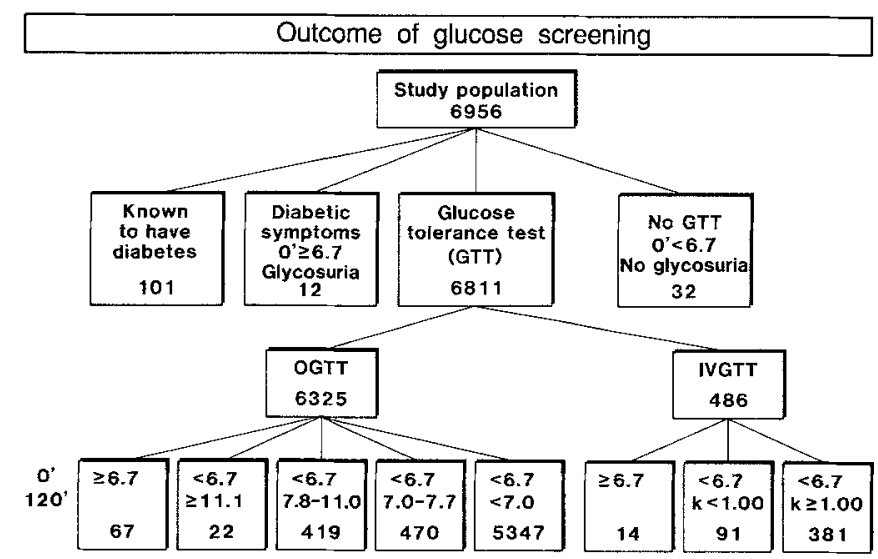

Fig. 2. Results of screening for impaired glucose tolerance and diabetes mellitus in the whole study population. Results of the oral glucose tolerance test are presented with the WHO (1985) criteria with the exception of separating subjects with $2 \mathrm{~h}$ values in the 7.0 $7.7 \mathrm{mmol} / \mathrm{l}$ range from normal subjects 
Table 1. Percentiles of fasting and $2 \mathrm{~h}$ blood glucose (mmol/l) during oral glucose tolerance test in the whole study population

\begin{tabular}{|c|c|c|c|c|c|c|c|c|c|c|}
\hline Percentiles & 1 & 5 & 10 & 25 & 50 & 75 & 90 & 95 & 99 & 100 \\
\hline \multicolumn{11}{|c|}{ Fasting glucose: } \\
\hline$n=6,948^{\mathrm{a}}$ & 3.4 & 3.8 & 4.0 & 4.3 & 4.7 & 5.1 & 5.6 & 6.0 & 8.9 & 20.1 \\
\hline$n=6,847^{b}$ & 3.4 & 3.8 & 4.0 & 4.3 & 4.7 & 5.1 & 5.5 & 5.8 & 6.9 & 18.4 \\
\hline$n=6,325^{c}$ & 3.5 & 3.8 & 4.0 & 4.3 & 4.7 & 5.1 & 5.5 & 5.8 & 6.7 & 12.5 \\
\hline
\end{tabular}

2 h glucose:

$\begin{array}{lllllllllll}n=6,325^{c} & 2.8 & 3.3 & 3.7 & 4.4 & 5.3 & 6.4 & 7.4 & 8.3 & 10.6 & 20.5\end{array}$

$n=$ number of subjects studied. " Cases of previously known diabetes included ( $n=101)$. In eight subjects (of 6,956) fasting values failed. ${ }^{b}$ Cases of previously known diabetes excluded. ${ }^{c}$ Subjects in whom an oral glucose tolerance test was performed

With regard to the non-responders, a search was made in patient records at the Internal Medicine Outpatient Clinic, the Diabetes Care Unit, and the central hospital archives (the city region is served by one main hospital which treats most of the local diabetic patients). At the time of screening, $3.9 \%$ of subjects were registered diabetic, which is twice the rate in the responder group $(p<0.001)$. If undetected diabetes is estimated at the same rate in the non-responder group as in the responder group, the prevalence of diabetes in the non-responder group would be $5.5 \%$. In the cohort as a whole, the prevalence could be estimated to be $3.7 \%$.

\section{Outcome of the GTTs (Fig. 2)}

GTT was performed in $98 \%$ of the study population. The screening outcome is summarised in Figure 2. OGTT was normal in $92.0 \%$ and impaired in $6.6 \%$, and diabetes was found in $1.4 \%$. With the lower cut-off level for IGT in use at the department at the time of screening $(2 \mathrm{~h}$ value $\geq 6.6 \mathrm{mmol} / \mathrm{l}$ before the SI-system and later $\geq 7.0 \mathrm{mmol} / \mathrm{l}), 653$ of the normal cases ( 183 cases in the $6.6-6.9 \mathrm{mmol} / 1 \mathrm{range}$ and 470 cases in the $7.0-7.7 \mathrm{mmol} / 1$ range) were also regarded as IGT cases, the subjects being invited to a second test.

IVGTT results were normal in $78.4 \%, 18.7 \%$ had kvalues $<1.00 \% / \mathrm{min}$ but normal fasting values, and $2.9 \%$ had increased fasting values. The mean $k$-value $( \pm \mathrm{SD})$ was $1.48 \pm 0.61 \% / \mathrm{min}$ (range $0.41-5.00 \% / \mathrm{min} ; 2.7 \%$ of all values $<0.50 \% / \mathrm{min}$ and $17.3 \%$ in the $0.50-0.99 \% / \mathrm{min}$ range).
In Table 1, fasting and $2 \mathrm{~h}$ glucose values are given as percentiles. The mean and SD of fasting glucose values in the study population as a whole are 4.84 and $1.07 \mathrm{mmol} / \mathrm{l}$, respectively. If previously known diabetic subjects and subjects in whom OGTT was not performed are excluded, the corresponding figures are 4.77 and $0.77 \mathrm{mmol} / 1$ (fasting values); 5.50 and $1.62 \mathrm{mmol} / \mathrm{l}$ ( $2 \mathrm{~h}$ values $)$. The correlation coefficient between fasting and $2 \mathrm{~h}$ values was 0.45 ( $p<0.001 ; 6,325$ observations).

In Table 2, mean values for body weight, body mass index, maximal oxygen uptake, and fasting and $2 \mathrm{~h}$ blood glucose are given for the different categories of glucose tolerance. There is a strong relationship between glucose values and both weight and maximal oxygen uptake. The highest mean weight and lowest oxygen uptake is found in conjunction with newly detected diabetes (mainly asymptomatic), whereas the IGT state is characterised by moderate overnight and moderately reduced oxygen uptake.

Table 3 shows the outcome of first and second OGTTs for the 889 retested cases; cases are divided into four categories according to the $2 \mathrm{~h}$ value at the first test to make further comparison possible. The wide individual fluctuation is unmistakable, and it is noteworthy that, on re-testing within one month, only $31 \%$ of those originally meeting the WHO criterion of IGT had a comparable test outcome, and in $62 \%$ the value had fallen below the cut-off level, while $49 \%$ were even below $7.0 \mathrm{mmol} / \mathrm{l}$. Reproducibility was highest in the diabetic group. There was relatively little increase in glucose intolerance (diabetes being diagnosed in only $7 \%$ of the IGT group at the repeat test).

Table 4 shows the mean values for fasting and $2 \mathrm{~h}$ blood glucose during the two OGTTs and corresponding body weights. The mean difference in fasting values between the first and the second test was negligible, while the mean $2 \mathrm{~h}$ value was $15 \%$ lower on retest. Mean body weight was unchanged between the two tests.

To ascertain whether persistence of IGT is related to physiological variables and metabolic profile, nondiabetic subjects who underwent a second OGTT were divided into three groups (Table 3$)$ : Group $1(n=109)$, IGT according to WHO on both tests; Group $2(n=221)$, IGT on first test; second test being normal $(2 \mathrm{~h}$ value $<7.8 \mathrm{mmol} / \mathrm{l})$; Group $3(n=104)$, high normal result on first test ( $2 \mathrm{~h}$ value in the $7.0-7.7 \mathrm{mmol} / \mathrm{l}$ range), second test outcome in the $7.0-11.0 \mathrm{mmol} / \mathrm{l}$ range. Table 5 gives the mean values for these three groups. Analysis of variance showed no differences between groups vis-à-vis body

Table 2. Body weight, body mass index, oxygen uptake and blood glucose by glucose tolerance as assessed with the OGTT

\begin{tabular}{|c|c|c|c|c|}
\hline Variable & $\begin{array}{l}\text { Glucose } 0^{\prime} \geq 6.7 \\
\text { and/or } 2 \mathrm{~h} \geq 11.1 \\
n=101(1)\end{array}$ & $\begin{array}{l}\text { Glucose } 0^{\prime}<6.7 \\
\text { and } 2 \text { h } 7.8-11.0 \\
n=419(2)\end{array}$ & $\begin{array}{l}\text { Glucose } 0^{\prime}<6.7 \\
\text { and } 2 \text { h } 7.0-7.7 \\
n=470(3)\end{array}$ & $\begin{array}{l}\text { Glucose } 0^{\prime}<6.7 \\
\text { and } 2 \mathrm{~h}<7.0 \\
n=5,347(4)\end{array}$ \\
\hline Body weight (kg) & $86.4 \pm 14.3$ & $81.5 \pm 12.3$ & $80.2 \pm 11.3$ & $76.9 \pm 11.1$ \\
\hline Maximal oxygen uptake $(1 / \mathrm{min})^{\mathrm{a}}$ & $2.34 \pm 0.71$ & $2.46 \pm 0.72$ & $2.57 \pm 0.61$ & $2.79 \pm 0.69$ \\
\hline Maximal oxygen uptake $\left(\mathrm{ml} \cdot \mathrm{kg}^{-1} \cdot \mathrm{min}^{-1}\right)^{\mathrm{a}}$ & $27.5 \pm 6.3$ & $30.8 \pm 8.6$ & $32.2 \pm 7.4$ & $36.6 \pm 9.0$ \\
\hline Fasting blood glucose $(\mathrm{mmol} / \mathrm{l})$ & $7.7 \pm 2.3$ & $5.1 \pm 0.6$ & $5.0 \pm 0.6$ & $4.7 \pm 0.6$ \\
\hline
\end{tabular}

$n=$ number of subjects studied; mean \pm SD. ${ }^{a}$ Ergometry was performed in $28(1), 194(2), 165(3)$ and $220(4)$ subjects. ${ }^{b}$ Missing $2 \mathrm{~h}$ value in 12 cases in whom OGTT was not performed due to overt diabetic symptoms. All groups had significantly different values $(p<0.05)$ for all variables 
Table 3. Outcome of first and second oral glucose tolerance test by levels at first test

\begin{tabular}{|c|c|c|c|c|}
\hline 2nd test & $\begin{array}{l}\text { Glucose } 0 \mathrm{~min} \geq 6.7 \\
\text { and/or } 2 \mathrm{~h} \geq 11.1 \\
n=51\end{array}$ & $\begin{array}{l}\text { Glucose } 0 \text { min }<6.7 \\
\text { and } 2 \text { h } 7.8-11.0 \\
n=353\end{array}$ & $\begin{array}{l}\text { Glucose } 0 \text { min }<6.7 \\
\text { and } 2 \mathrm{~h} 7.0-7.7 \\
n=370\end{array}$ & $\begin{array}{l}\text { Glucose } 0 \text { min }<6.7 \\
\text { and } 2 \text { h } 6.6-6.9 \\
n=115\end{array}$ \\
\hline Glucose $0 \mathrm{~min} \geq 6.7 \mathrm{and} /$ or $2 \mathrm{~h} \geq 11.1$ & 23 & 23 & 7 & 0 \\
\hline Glucose $0 \mathrm{~min}<6.7$ and $2 \mathrm{~h} 7.0-7.7$ & 5 & $47^{\mathrm{b}}$ & $60^{c}$ & 6 \\
\hline Glucose $0 \mathrm{~min}<6.7$ and $2 \mathrm{~h} 6.6-6.9$ & 2 & $34^{\mathrm{b}}$ & 35 & 5 \\
\hline Glucose $0 \mathrm{~min}<6.7$ and $2 \mathrm{~h}<6.6$ & 6 & $140^{\mathrm{b}}$ & 224 & 96 \\
\hline
\end{tabular}

$n=$ number of subjects studied ${ }^{a-c}$ indicate groups $1-3$, further analysed in Table 5

Table 4. Glucose values during first and second oral glucose tolerance test and corresponding body weights in 889 cases with abnormal first test results

\begin{tabular}{|c|c|c|c|c|c|c|c|c|c|c|c|c|}
\hline & \multicolumn{4}{|c|}{ 1st test } & \multicolumn{4}{|c|}{ 2nd test } & \multicolumn{4}{|l|}{ Diff $^{a}$} \\
\hline & Mean & SD & $\min$ & $\max$ & Mean & SD & $\min$ & $\max$ & Mean & SEM & $\%$ & $p^{b}$ \\
\hline Fasting blood glucose $(\mathrm{mmol} / \mathrm{l})$ & 5.1 & 0.7 & 3.2 & 9.1 & 5.1 & 0.8 & 3.0 & 8.7 & -0.1 & 0.0 & -0.7 & 0.004 \\
\hline
\end{tabular}

a 2 nd value minus 1 st value (values are rounded off to one decimal); ${ }^{b} p$-value for paired $t$-test

weight, BMI, triceps skin fold index, diastolic blood pressure, first fasting glucose and insulin values, first $2 \mathrm{~h}$ postload insulin values or blood lipids, though maximal oxygen uptake and systolic blood pressure differed significantly between the groups $(\mathrm{p}<0.005 ; \mathrm{p}<0.02)$. Mean values for oxygen uptake were similar in groups 1 and 3 , and significantly lower than in group $2(\mathrm{p}<0.003$; $\mathrm{p}<0.02$ ). Systolic blood pressure was higher in both IGT groups than in the high normal group, though there was no difference between the two IGT groups despite the different outcome of the second test. Although all cases in groups 1 and 2 had IGT at the first test, the mean $2 \mathrm{~h}$ glucose value was higher in group 1 . The $2 \mathrm{~h}$ glucose value at the second test was by definition lower in group 2 , and the $2 \mathrm{~h}$ insulin level showed a concomitant fall. There was a tendency (just below the level of significance) toward increased plasma triglycerides in group 1 (significant if only the two IGT groups were compared $(\mathrm{p}<0.02))$, while no differences were found between any of the three groups with regard to plasma cholesterol.

\section{Discussion}

Further epidemiological studies are needed $[16,30]$ to improve our understanding of the determinants involved in the deterioration process from normal or impaired glucose tolerance to manifest diabetes. It is thus an advantage to have a large, homogenous and well-defined study population, especially when the prevalence of known diabetes is low (about $2 \%$ ) in the urban area in question. In this respect, our study population was satisfactory with an attendance rate of $77 \%$, although there may have been a minor degree of selection as the prevalence of known diabetes was higher in the non-responder group than in the cohort as a whole. The $2.0 \%$ prevalence of previously known diabetes in the whole cohort is comparable to that of diabetes in Sweden as a whole, for males in this age group [31], though it is only half that reported in the USA $[32,33]$. However, the proportion of previously undiagnosed cases was comparable to that in the USA (i.e., about the same as that for previously known cases in this age group).

The epidemiological data may have been affected by the loading dose used for the OGTT being slightly smaller than that now recommended by the WHO $[34,35]$. In a smaller Swedish study [36], however, no significant difference in effect on the $2 \mathrm{~h}$ value was found between a dosage of $30 \mathrm{~g} / \mathrm{m}^{2}$ body surface area and a fixed dose of $75 \mathrm{~g}$ in each subject. Moreover, the use of duplicate blood samples for the cut-off values, as adopted in this study, increases the reliability of the glucose values and minimises the risk of laboratory error.

In this study, the GTT was performed in the whole responder group under strictly standardised conditions after subjects had fasted overnight. In many studies, the OGTT has been performed in selected groups only, for example in cases with glycosuria, and often under varying conditions. In view of the substantial individual fluctuation in glucose tolerance and low reproducibility of the OGTT previously reported $[18,37-40]$, the result of a single OGTT is of rather low predictive value.

As the screening procedure used here included re-testing of all abnormal cases, it was possible to study and quantify the natural fluctuations in glucose tolerance in a large group of cases (about 900) with initially high fasting or post-load glucose values. Of all cases subjected to OGTT, $4.1 \%$ had a $2 \mathrm{~h}$ value in the $7.0-11.0 \mathrm{mmol} / \mathrm{l} \mathrm{range}$ on both tests compared to $6.6 \%$ with a $2 \mathrm{~h}$ value in the 7.8 $11.0 \mathrm{mmol} / \mathrm{l}$ range (WHO criterion) at the first test only. However, owing to the low reproducibility only half of the cases identified were identical as established with both procedures (i.e., the WHO criterion and repeat testing at our cut-of level) (Table 3), which implies the existence of different subgroups of IGT. It was found that $2 \mathrm{~h}$ values decreased by as much as $15 \%$ on average, the fall being unrelated to any change in weight. The fall is mainly to be explained by the regression-to-the-mean phenomenon, although smaller variation in the intake of carbohydrates during the interval between the tests and relief of anxiety about the investigation may be of some importance. 
Table 5. Physiological and metabolic variables in groups ${ }^{\mathrm{a}}$ with stable and with fluctuating impaired glucose tolerance

\begin{tabular}{|c|c|c|c|c|}
\hline Variable & $\begin{array}{l}\text { Group } 1 \\
n=109\end{array}$ & $\begin{array}{l}\text { Group } 2 \\
n=221\end{array}$ & $\begin{array}{l}\text { Group } 3 \\
n=104\end{array}$ & $p$-value \\
\hline Body weight $(\mathrm{kg})$ 1st test & $83.3 \pm 10.3$ & $\begin{array}{l}80.8 \pm 13.2 \\
806+130\end{array}$ & $\begin{array}{l}81.8 \pm 11.8 \\
819+121\end{array}$ & NS \\
\hline Triceps skin fold index & $203 \pm 19$ & $203 \pm 19$ & $203 \pm 18$ & NS \\
\hline Maximal oxygen uptake (1/min) & $2.34 \pm 0.54(2)$ & $2.63 \pm 0.68(1,3)$ & $2.39 \pm 0.59(2)$ & 0.0044 \\
\hline Systolic blood pressure $(\mathrm{mm} \mathrm{Hg})$ & $139 \pm 16$ & $142 \pm 20(3)$ & $136 \pm 19(2)$ & 0.0110 \\
\hline Diastolic blood pressure $(\mathrm{mm} \mathrm{Hg})$ & $92 \pm 10$ & $94 \pm 12$ & $93 \pm 12$ & NS \\
\hline $\begin{array}{l}\text { Fasting glucose }(\mathrm{mmol} / \mathrm{l}) 1 \mathrm{st} \text { test } \\
\text { Fasting glucose }(\mathrm{mmol} / \mathrm{l}) 2 \text { nd test }\end{array}$ & $\begin{array}{l}5.2 \pm 0.6 \\
5.2 \pm 0.7(2)\end{array}$ & $\begin{array}{l}5.1 \pm 0.6 \\
5.0 \pm 0.6(1,3)\end{array}$ & $\begin{array}{l}5.0 \pm 0.6 \\
5.1 \pm 0.7(2)\end{array}$ & $\begin{array}{l}\text { NS } \\
0.0009\end{array}$ \\
\hline $\begin{array}{l}2 \mathrm{~h} \text { glucose }(\mathrm{mmol} / \mathrm{l}) 1 \mathrm{st} \text { test } \\
2 \mathrm{~h} \text { glucose }(\mathrm{mmol} / \mathrm{l}) 2 \mathrm{nd} \text { test }\end{array}$ & $\begin{array}{l}9.0 \pm 0.8(2,3) \\
8.7 \pm 0.8(2,3)\end{array}$ & $\begin{array}{l}8.5 \pm 0.7(1,3) \\
6.1 \pm 1.0(1,3)\end{array}$ & $\begin{array}{l}7.3 \pm 0.2(1,2) \\
7.8 \pm 0.9(1,2)\end{array}$ & $\begin{array}{l}0.0 \\
0.0\end{array}$ \\
\hline $\begin{array}{l}2 \mathrm{~h} \text { insulin }(\mathrm{mIU} / \mathrm{l}) 1 \mathrm{st} \text { test } \\
2 \mathrm{~h} \text { insulin }(\mathrm{mIU} / 1) 2 \mathrm{nd} \text { test }\end{array}$ & $\begin{array}{l}106.3 \pm 6.5 \\
102.5 \pm 6.6(2)\end{array}$ & $\begin{aligned} 101.1 & \pm 6.7 \\
56.3 & \pm 3.2(1,3)\end{aligned}$ & $\begin{array}{l}81.6 \pm 5.6 \\
87.9 \pm 5.8(2)\end{array}$ & $\begin{array}{l}\text { NS } \\
0.0001\end{array}$ \\
\hline Plasma cholesterol (mmol/l) 1st test & $5.83 \pm 0.98$ & $5.97 \pm 1.09$ & $5.85 \pm 0.87$ & NS \\
\hline Plasma triglycerides $(\mathrm{mmol} / \mathrm{l}) 1 \mathrm{st}$ test & $2.27 \pm 0.13$ & $1.92 \pm 0.01$ & $1.96 \pm 0.15$ & NS \\
\hline
\end{tabular}

a Group 1 = IGT ( $2 \mathrm{~h}$ value in the 7.8-11.0 range) on both tests; Group 2 = IGT on first test; second test being normal ( $2 \mathrm{~h}$ value $<7.8 \mathrm{mmol} / \mathrm{l})$ Group $3=$ High normal on first test ( $2 \mathrm{~h}$ value in the $7.0-7.7 \mathrm{mmol} / \mathrm{h}$ range) and second test with a $2 \mathrm{~h}$ value in the $7.0-11.0 \mathrm{mmol} / \mathrm{h} \mathrm{range}$. See also Table 3 for group definition; Mean \pm SD or SEM (insulin and triglycoride values). Figures in brackets indicate groups with significantly different values ( $p<0.05$ on $t$-test); $n=$ number of subjects; $\mathrm{n}$. $\mathrm{s} .=p \geq 0.05$ for F-value (analysis of variance), or the $p$-value is given

The finding of constant fasting glucose values is chiefly to be explained by the fact that most cases were selected for the repeat test on the basis of the $2 \mathrm{~h}$ value. The regression to the mean will thus not be comparable unless fasting and $2 \mathrm{~h}$ values are almost $100 \%$ correlated, in our study both values $(n=6,325)$ had an overall correlation coefficient of 0.45 (somewhat lower for lower values and somewhat higher for higher values), implying that each glucose level is independently subject to other factors as well (e.g., measurement error). In the group with diabetic symptoms, where only fasting glucose was measured on the first and repeat test (not included in Table 3), there was no mean difference between the first and second value, but decision to re-test was not based on the fasting value alone but on symptomatology as well.

A close overall correlation between maximal oxygen uptake and glucose tolerance, has been demonstrated in previous studies of ours in the same screening cohort [4143]. The indirect measurement of oxygen uptake used in the study, has been compared with a direct method, both in normal subjects and IGT cases, but no difference was found [44]. In the present study maximal oxygen uptake was significantly lower in IGT cases where the OGTT result was reproducible (group 1), and in cases with intermediate but persistent values (group 3), than in IGT cases with normal repeat test results (group 2). Reduced oxygen uptake has been found to be coupled to reduced insulin sensitivity $[41,43]$ and in a previous study [45] oxygen uptake was found to be low in cases with IGT, indicating a more severe metabolic disturbance and a reduced metabolic potential in skeletal muscle. The present findings of a persistent increase in the $2 \mathrm{~h}$ insulin level and a tendency toward increased triglycerides also support this idea of a more pronounced insulin resistance in cases with reproducible IGT. Fluctuators (group 2) were found to have a somewhat higher systolic but not diastolic blood pressure, which may indicate that stress is a factor of importance with regard to the non-reproducible OGTT result.

Although a number of studies have shown baseline glucose values to be the best predictors of future diabetes [3-12], there has been no evaluation of the risk of diabetes in patients with IGT and poor physical fitness but with little fluctuation in glucose tolerance. Fluctuation in combination with normal physical fitness may indicate a milder degree of IGT and preventive efforts in such cases could be reduced. To increase the specificity and predictive value of the OGTT we would recommend the use either of the repeat test procedure, and in that case at a lower cut-off level for the $2 \mathrm{~h}$ value to obtain enough cases, or to extend the investigation by including ergometry, or both, when IGT cases are selected for long-term studies.

Acknowledgements. This work was supported by grants from the Ernhold Lundström Foundation, the Swedish Diabetes Association, the Swedish National Association against Heart and Chest Diseases, the Medical Faculty, University of Lund, Sweden, and Novo Industries.

\section{References}

1. Marble A (1974) The natural history of diabetes. Horm Met Res Suppl 4: 153-158

2. Królewski AS, Warran JH, Christlieb AR (1985) Onset, course, complications and prognosis of diabetes mellitus. In: Marble A, Krall LP, Bradley R, Christlieb AR, Soeldner JS (eds) Joslin's 
diabetes mellitus, 12th edn. Lea and Febiger, Philadelphia, pp 251-277

3. Keen H, Jarrett RJ, McCartney P (1982) The ten-year follow-up of the Bedford Survey (1962-1972): glucose tolerance and diabetes. Diabetologia 22: 73-78

4. Jarrett RJ, Keen H, Fuller JH, McCartney M (1979) Worsening to diabetes in men with impaired glucose tolerance ("borderline diabetes"). Diabetologia 16:25-30

5. Sartor G, Scherstén B, Carlström S, Melander A, Nordén A, Persson G (1980) Ten-year follow-up of subjects with impaired glucose tolerance. Diabetes 29:41-49

6. Papoz L, Eschwege E, Warnet J-M, Richard J-L (1982) Incidence and risk factors of diabetes in the Paris prospective study (G.R.E.A.). Advances in Diabetes Epidemiology. INSERM symp 22. Elsevier Biomedical Press, Amsterdam, pp 113-122

7. Kadowaki T, Miyake Y, Hagura R, Akanuma Y, Kajinuma H, Kuzuya N, Takaku F, Kosaka K (1984) Risk factors for worsening to diabetes in subjects with impaired glucose tolerance. Diabetologia 26: $44-49$

8. Sasaki A, Suzuki T, Horiuchi N (1982) Development of diabetes in Japanese subjects with impaired glucose tolerance: a seven year follow-up study. Diabetologia 22: 154-157

9. King H, Zimmet P, Raper LR, Balkau B (1984) The natural history of impaired glucose tolerance in the Micronesian population of Nauru: a six year follow-up study. Diabetologia 26: 39-43

10. Balkau B, King H, Zimmet P, Raper LR (1985) Factors associated with the development of diabetes in the Micronesian population of Nauru. Am J Epidemiol 122: 594-605

11. Agner E, Thorsteinsson B, Eriksen M (1982) Impaired glucose tolerance and diabetes mellitus in elderly subjects. Diabetes Care 5:600-604

12. Sigurdsson G, Gottskálksson G, Thorsteinsson T, Davidsson D, Olafsson O, Samuelsson S, Sigfusson N (1981) Community screening for glucose intolerance in middle-aged Icelandic men. Acta Med Scand 210:21-26

13. Zimmet $P$, King $H$ (1985) The epidemiology of diabetes mellitus: recent developments. In: Alberti KGMM, Krall LP (eds) The Diabetes Annual/1. Elsevier, Amsterdam, pp 1-15

14. Scherstén B, Bitzén P-O (1984) The diagnosis of diabetes mellitus. Acta Endocrinol [Suppl] 262: 11-17

15. National Diabetes Data Group (1979) Classification and diagnosis of diabetes mellitus and other categories of glucose intolerance. Diabetes 28: 1039-1057

16. WHO (1985) Expert committee on diabetes mellitus. Third report. WHO Tech Rep Ser 727, pp 1-113

17. Siperstein MD (1975) The glucose tolerance test: a pitfall in the diagnosis of diabetes mellitus. Ann Int Med 20: 297-323

18. McDonald GW, Fisher G, Burnham C (1965) Reproducibility of the oral glucose tolerance test. Diabetes 14: 473-480

19. West KM (1978) Epidemiology of diabetes and its vascular lesions. Elsevier, New York

20. Riccardi G, Vaccaro O, Rivellese A, Pignalosa S, Tutino L, Mancini M (1985) Reproducibility of the new diagnostic criteria for impaired glucose tolerance. Am J Epidemiol 121: 422-429

21. Kristensson H, Trell E, Fex G, Hood B (1980) Serum $\gamma$-Glutamyltransferase: statistical distribution in a middle-aged male population and evaluation of alcohol habits in individuals with elevated levels. Prev Med 9: 108-119

22. Janzon L, Berntorp K, Hansson M, Lindell S-E, Trell E (1983) Glucose tolerance and smoking: A population study of oral and intravenous glucose tolerance tests in middle-aged men. Diabetologia 25: 86-88

23. Marks V (1959) An improved glucose-oxidase method for determining blood, c.s. f. and urine glucose levels. Clin Chim Acta 4: 395-400

24. Carrol JJ, Smith N, Babson AL (1970) A calorimetric serum glucose determination using hexokinase and glucose-6-phosphate dehydrogenase. Biochem Med 4: 171-180

25. Edwards DAW, Hammond WH, Healy MJR, Tanner JM, Whitehouse RH (1955) Design and accuracy of calipers for measuring subcutaneous tissue thickness. Br J Nutr 9: 133-144
26. Heding LG (1966) A simplified insulin radioimmunoassay method. In: Donato L, Milhaud G, Sirchis I (eds) Labelled proteins in tracer studies. Euratom, Brussels, pp 345-350

27. Åstrand I (1960) Aerobic work capacity in men and women with special reference to age. Acta Physiol Scand 169 [Suppl]: 49-92

28. Ganrot PO, Laurell C-B, Lundh B, Nosslin B (1970) Clinical chemistry (in Swedish), 2nd edn. Studentlitteratur, Lund, pp 8588

29. Bondy P (1969) Disorders of carbohydrate metabolism. In: Bondy P, Rosenberg L (eds) Duncan's diseases of metabolism, 6 th edn. WB Saunders, Philadelphia London Toronto, pp 222224

30. Diabetes Epidemiology Workgroup (1981) National conference on Diabetes: Research needs in the epidemiology of diabetes. Am J Epidemiol 113: 105-112

31. Grönberg A, Larsson T, Ljung J (1967) Diabetes in Sweden. Acta Med Scand [Suppl] 477:1-275

32. National Diabetes Data Group (1985) Diabetes in America. NIH Publication No. 85-1468, pp VI-1-31

33. Harris MI, Hadden WC, Knowler WC, Bennett PH (1987) Prevalence of diabetes and impaired glucose tolerance and plasma glucose levels in U.S. population aged $20-74$ yr. Diabetes 36 : 523-534

34. Förster H, Haslbeck M, Mehnert H (1972) Metabolic studies following the oral ingestion of different doses of glucose. Diabetes 21: $1102-1108$

35. deNobel E, van't Laar A (1978) The size of the loading dose as an important determinant of the results of the oral glucose tolerance test. Diabetes 27: 42-48

36. Bitzén P-O, Melander A, Scherstén B (1984) How to screen for diabetes mellitus. Acta Endocrinol [Suppl] 262:37-41

37. Ganda OP, Day JL, Soeldner JS, Connon JJ, Gleason RE (1978) Reproducibility and comparative analysis of repeated intravenous and oral glucose tolerance tests. Diabetes 27:715-725

38. Kahn CB, Soeldner JS, Gleason RE, Rojas L, Camerini-Davalos RA, Marble A (1969) Clinical and chemical diabetes in offspring of diabetic couples. N Engl J Med 281: 343-347

39. Olefsky JM, Reaven GM (1974) Insulin and glucose responses to identical oral glucose tolerance tests performed forty-eight hours apart. Diabetes 23:449-453

40. Rushforth NB, Bennett PH, Steinberg AG, Miller M (1975) Comparison of the value of the two- and one-hour glucose levels of the oral GTT in the diagnosis of diabetes in Pima Indians. Diabetes 24: 538-546

41. Lindgärde F, Saltin B (1981) Daily physical activity, work capacity and glucose tolerance in lean and obese normoglycaemic middle-aged men. Diabetologia 20:134-138

42. Eriksson K-F, Lindgärde F (1988) Intervention strategy in impaired glucose tolerance - the role of physical fitness. In: Smith U, Eriksson S, Lindgärde F (eds) Genetic susceptibility to environmental factors - a challenge for public intervention. Almqvist \& Wiksell International Stockholm, Sweden, pp 75-81

43. Lindgärde F, Malmquist J, Balke B (1983) Physical fitness, insulin secretion and glucose tolerance in healthy males and mild type-2 diabetes. Acta Diabetol Lat 20: $33-40$

44. Berntorp K, Eriksson K-F, Lindgärde F (1986) The importance of diabetes heredity in lean subjects on insulin secretion, blood lipids and oxygen uptake in the pathogenesis of glucose intolerance. Diabetes Res 3: 231-236

45. Saltin B, Lindgärde F, Houston M, Hörlin R, Nygaard E, Gad P (1979) Physical training and glucose tolerance in middle-aged men with chemical diabetes. Diabetes 28 [Suppl 1]: 30-33

Received: 26 August 1988

and in final revised form: 28 February 1990

Dr. K.-F. Eriksson

Department of Medicine

Malmö General Hospital

S-214 01 Malmö

Sweden 